\title{
nature
}

\author{
8 October 1981
}

\section{What European policy on science?}

The appointment last week of Professor Paolo Fasella as Director-General of Research, Science and Education in Brussels is a surprising reminder that the European Community also has a stake in making policy on technical matters. Surprising? Because it is almost a decade since the Community did anything effective in this field (which does not mean that it has ever failed to keep the Joint Research Centre at Ispra in Italy supplied with funds). So why should the accession of Professor Fasella be taken as a sign that things may be different in the future? Because Fasella is an energetic man with a passion for building bridges between the universities and industry, because the community is coming to a point in its brief history - a mere quarter of a century - when an effective policy in regard to science and technology would be feasible and $\mid$ also becausel if Fasella, like his predecessors in Brussels, gets nowhere, that will be a sure sign that the community should give up the struggle, leaving policy in the field to member governments.

There are also two chief underlying difficulties, the most serious of which is constitutional. The European Commission is neither a government nor an independent agency, but a kind of judicial body empowered to implement the Treaty of Rome (which means that it can be tough about trade protection) but otherwise given a licence to function only when no substantial member government dissents. Since the treaty has nothing specific to say about science and technology (even though quite a lot about nuclear energy, a hangover from the Euratom Treaty), successful initiatives require the support of member governments. This is why, more than a decade ago, M. Pierre Aigrain's ambitious schemes for the creation of a European computer and communications industry came to nothing; most governments were opposed to change.

The other difficulty that Professor Fasella will run up against in Brussels is that the European Commission, although widely reviled as a gigantic bureaucracy, lacks many of the rudimentary facilities governments have at their disposal. People may be wellpaid by national standards, but there are only handfuls of them, not often distinguished intellectually or as administrators. Advisory groups, expected to reflect a kind of national balance, are too impermanent to be of substantial help to those in charge of policy. And, in the competitive hothouse of Brussels, directorsgeneral have an incentive to strike out in adventurous, even noisy, directions rather than to ensure that the Community's administration of science and technology is conducted sensibly. Professor Fasella will be well advised if, for a time at least, he can stay out of that rat-race.

But what else is there to do in Brussels? Unenviably, the Community has acquired in the past decade or more a reputation for naivety in technical affairs that would cause even the smallest local authorities to hang their heads. In devising policies for regulating pollution, the manufacture of toxic chemicals or even the allocation of fishing rights in Community waters, the commission has often behaved like a bunch of lawyers seeking to ensure that everything will be for the best in some unreal world. The most urgent task, for Professor Fasella, is somehow to ensure that the commission's routine regulatory work, its bread and butter, is technically competent. That is far from easy - the directorates at Brussels are notoriously balkanized. Directorsgeneral seem mostly to be bound by the convention that they should not seek to influence each other's affairs. Professor Fasella should avoid that trap.
He should also avoid the trap of the spectacular initiative some great plan for the reinvigoration of European metalforming technology, submarine cargo transport or even airship technology. Such schemes have foundered in the past, and will continue to founder, on the jealous self-interest of member governments, to whom collaborative projects are attractive only when they are sure of being able to recover at least as much money (by way of contracts for their own nationals) as they contribute. (The European thermonuclear project JET is an exception only because its possible application lies some way ahead.) In the long run, the only stable solution is that governments should agree that contracts for public purchases should be made competitively. (At present, the Treaty of Rome excepts governments from the rules of competition that apply to private companies and individuals.) It would be asking a lot that a mere director-general of research, science and education should solve that problem single-handed. Professor Fasella should, however, keep it in mind.

For the rest, Professor Fasella's most constructive work will seem quite humdrum. $\mathrm{He}$, and the Community, must take an interest in the wellbeing of the scientific community. The encouraging signs, in the 1960 s, of a growing sense of integration within European science faltered in the 1970 s, as national governments ran out of the funds with which to pay for ad hoc schemes. There is now a danger that collaboration between European scientists will be further restricted. The Community has an interest to ensure that this does not happen, and the commission has a duty in the same direction. Quite modest funds would help. But instead of working through cumbersome ad hoc instruments (or even the apparently useless committee called GERD), the commission should work directly with national research councils, perhaps in the form of the European Science Foundation. Professor Fasella should cut his teeth on modest tasks like that.

\section{Off with their heads!}

President Reagan did not, as is now widely supposed, abolish the Departments of Energy and of Education in his television broadcast two weeks ago. Instead, he said that he proposed that they should be abolished. What will now happen is that the White House will prepare plans for deciding how the statutory obiigations of the two departments should be transferred elsewhere (or perhaps even liquidated). Congress will then say whether it approves the plan - and in the process there will no doubt be an unholy fight about the propriety of what is proposed: the Department of Education was, after all, one of President Carter's concessions to liberal opinion. Then, two or three years from now, the two departments may go out of business. President Reagan thus reaped the benefit of practising what he was preaching last November - the benefit of small government but neither department has disappeared yet.

It is not even clear what plans the White House will be putting forward. The Department of Energy, which did not exist eight years ago, will not be unscrambled easily. For the department has been saddled with responsibility for the torrent of legislation on energy matters that Congress has been passing in the past few years including the Energy Act of 1977 which, inter alia, solemnly declares that "this Congress considers that the bicycle is the most economical form of transport". The department superintends the regulation (or deregulation) of prices for oil and natural gas, 